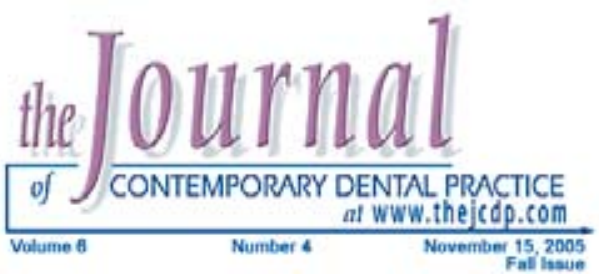

\title{
Clinical Management of the Dental Patient Taking Multiple Drugs
}

\section{Peter L. Jacobsen, PhD, DDS; Elisa M. Chávez, DDS}

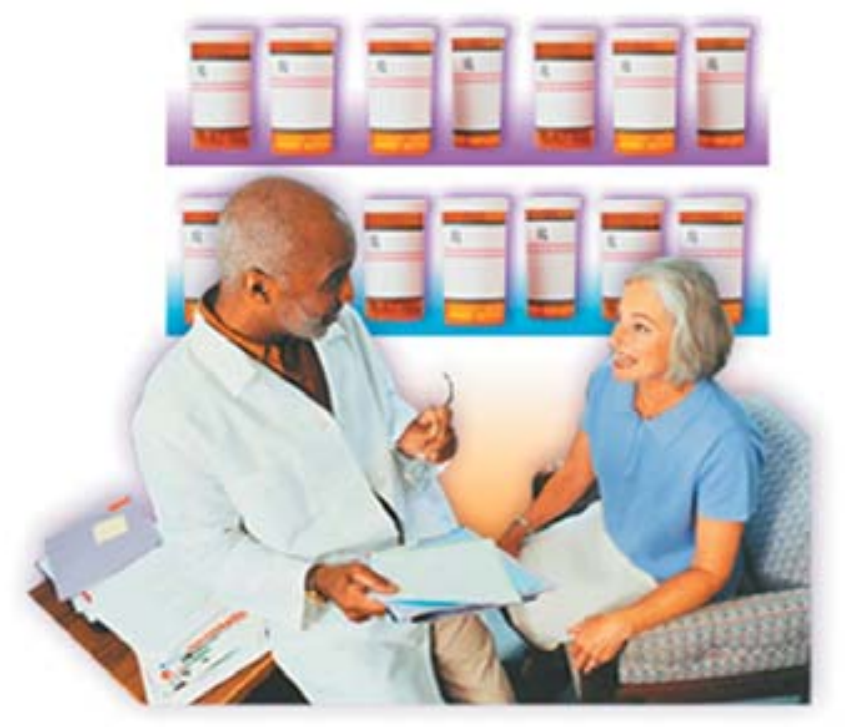

\section{Abstract}

Adverse drug reactions (ADRs) occur often in elders often due to polypharmacy. Those over 65 currently comprise $13 \%$ of the population but consume approximately a third of all drugs prescribed. Increased care when prescribing certain drug classes and careful monitoring of the patient can prevent many ADRs. This article examines four questions that should be addressed when providing dental care for an older patient taking multiple medications. These include: (1) what are the medical conditions that necessitate the medications, (2) what impact do these medical conditions have on the provision of care, (3) what are the oral side effects of the medications, and (4) how will the patient's current list of medications alter the dentist's prescribing patterns for drugs used in dentistry?

Keywords: Polypharmacy, geriatrics, dental, adverse drug reactions, ADRs

Citation: Jacobsen PL, Chávez EM. Clinical Management of the Dental Patient Taking Multiple Drugs. J Contemp Dent Pract 2005 November;(6)4:144-151.

(C) Seer Publishing 
Introduction

In the dental office an adverse drug reaction (ADR) (See Table 1) may occur with the administration of even a single drug. The risk of an ADR increases when managing patients on multiple medications for multiple diseases. Forty percent of seniors take an average of three medications. ${ }^{1}$ As the population ages, the number of patients with chronic diseases taking multiple medications (polypharmacy) increases. ${ }^{2}$ By the year 2030 it is expected individuals over 65 years of age will compose $20 \%$ of the population, and the group over 85 will almost double in number. Those over 65 currently comprise $13 \%$ of the population but consume approximately a third of all drugs prescribed. ${ }^{1,3}$

\section{Adverse Drug Reaction Risk}

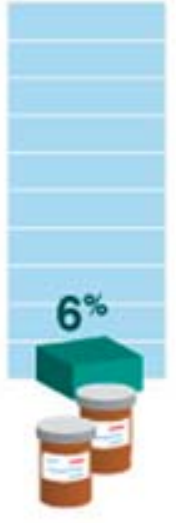

2 drugs

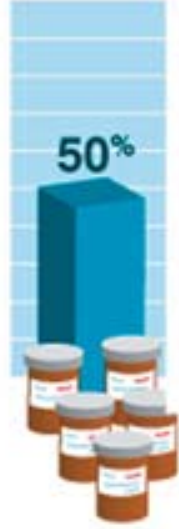

5 drugs

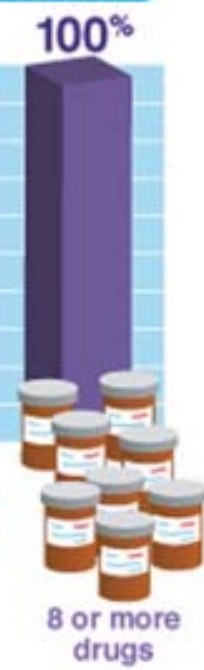

ADRs occur more often in elders, for a variety of reasons, but are often due to polypharmacy. The risk increases for those who are malnourished or have renal or hepatic diseases, diabetes, asthma, or other systemic diseases. ${ }^{1}$ The potential risk of an adverse reaction rises from $6 \%$ with two drugs, to $50 \%$ with five drugs, and $100 \%$ with eight or more medications. ${ }^{4-6}$ Studies have shown prevalence rates of $10-35 \%$ for ADRs in community dwelling elders. ${ }^{4}$ Several studies examining community dwelling elders ${ }^{4}$, institutionalized frail elders ${ }^{7,8}$, and hospitalized elders ${ }^{9}$ have shown that as the number of prescribed drugs increases the occurrence of ADRs also increases.
In the dental setting, as well as in the medical setting, a thorough health history, increased care when prescribing certain drug classes, and careful monitoring of the patient can prevent most of these ADRs. ${ }^{1,3,4}$ This article presents a framework for evaluating and managing patients on multiple medications (See Table 2). It examines four areas of concern when providing dental care for an older patient taking multiple medications: (1) medical conditions that necessitate the medications, (2) the impact these medical conditions have on the provision of care, (3) the oral side effects of the medications, and (4) the impact of the patient's current list of medications on the dentist's prescribing patterns for drugs used in dentistry.

\section{Identify Medical Conditions Necessitating The Drug And Its Potential Impact On The} Provision Of Dental Care

When a patient presents with a lengthy medication list, a primary concern is whether or not there are medications on the list that may be required in the event of an emergency. The patient's drugs should be categorized to identify immediate safety considerations, i.e., grouping the drugs by classes: anticoagulant, anti-anginal, hypoglycemics, etc. For example, does the patient require nitroglycerin for angina ${ }^{10}$ or an inhaler for dyspnea? ${ }^{11}$ If so, these drugs should be available during the dental appointment. Secondly, do any of the drugs on the list have the potential to complicate dental treatment? For example, is the patient taking the anti-coagulant Warfarin? If so, has the patient's physician been alerted to the pending dental treatment and have all the necessary lab tests been run and the results available? Has the patient taken their dose of insulin but not eaten, placing them at risk for hypoglycemia? ${ }^{12}$ Third, could any

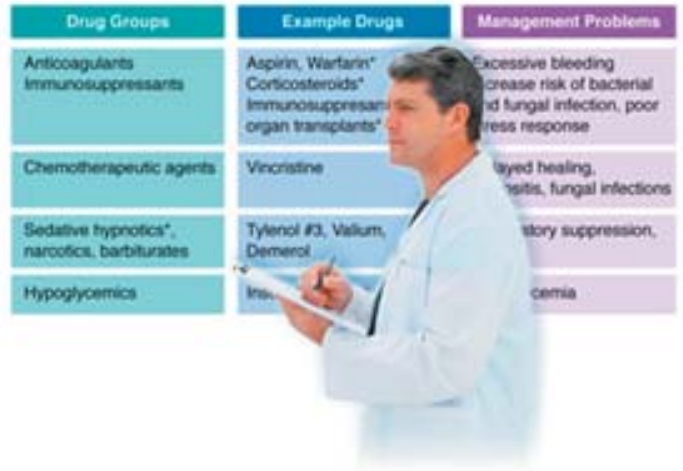


of the medications compromise our treatment outcomes? For example, is the healing time or risk of infection increased because the patient is on immunosuppressants such as Prednisone ${ }^{13,14}$ or chemotherapeutics such as Vincristine or Methotrexate ? $^{14}$

The clinician should be alert to any highly titrated drugs with a narrow margin of safety, which may increase the risk of an adverse drug event ${ }^{15,16}$ (Table 3A). Many natural products can have a physiologic impact that requires altered dental management, so the clinician should be sure to inquire if the patient is taking any natural products (Table 3B).

Reviewing with the patient the indications for all medications on the list allows the dentist the opportunity to clarify the health history and provides important information about the patient and any potential risks or management issues to be considered when treating the patient. In some cases the patient will not be able to effectively communicate their health issues, in which case their medication list may be the dental clinician's only immediate resource for identifying medical problems which are so severe they require pharmacologic intervention. For instance, a patient may not report they have hypertension, but their medication list may include Furosemide, a diuretic. ${ }^{14}$ Both the hypertension and the diuretic can have implications on the provision of dental care as well as direct and indirect effects on the patient's oral health.

\section{Identify Drugs With The Potential For Oral Side Effects}

Identifying drugs by class is also important because certain classes of drugs are more likely to result in specific types of oral pathology (Table 4). For example, ACE inhibitors and other drugs are associated with lichenoid reactions ${ }^{3,17,18}$, diuretics and antidepressants could contribute to xerostomia $^{3,18,19,20}$, and calcium channel blockers and some anti-seizure and immunosuppressant drugs can contribute to gingival hyperplasia., ${ }^{3,121}$ Many medications result in altered taste sensations that, in severe cases, can result in nutritional deficiencies and malnutrition, which can lead to oral changes. ${ }^{21,22,23}$ Xerostomia is one of the most common and potentially destructive oral side effect of drugs. It can contribute to an increase in caries and an increased susceptibility
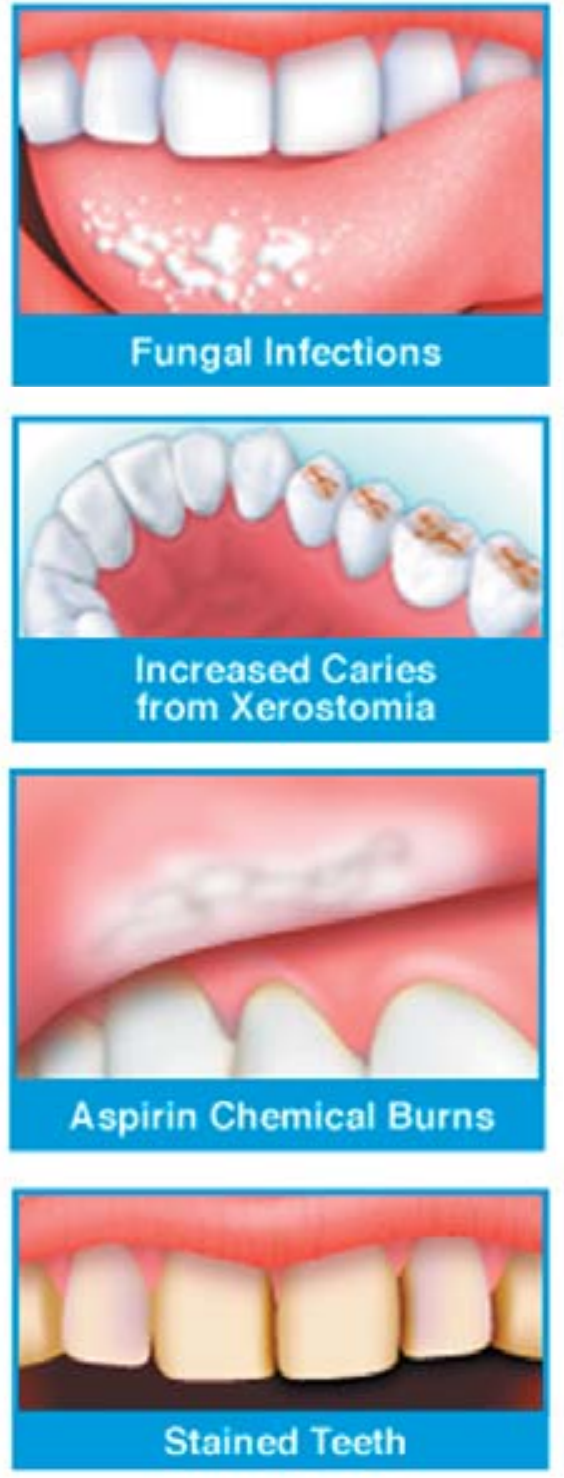

to oral fungal infections. In the aged it can also result in easily traumatized mucosal tissues. Dry mouth can reduce or alter the sensation of taste as well as impair speech and swallowing function. ${ }^{1,3,5,19,20}$ The dentist may consult with the patient's physician about changing a xerostomic medication to another. However, for patients on numerous medications that cause xerostomia, only palliative therapy such as salivary substitutes and lubricants may be all that is possible. For dentate patients, management of xerostomia should include caries prevention.

Sometimes oral pathology is a result of a specific medication, exacerbated by poor oral hygiene, such as gingival hyperplasia in patients taking Dilantin for seizure disorders. ${ }^{21}$ 
Some medications, such as aspirin, may result in a chemical burn if they are misused and placed directly on the oral tissue. Interestingly, even adult teeth can become discolored from tetracycline - specifically minocycline. These oral conditions may require treatment, palliation, and/ or preventive measures, which may sometimes include adding another medication to an already long list. ${ }^{3,5,24}$

\section{Create A System For Prescribing}

After carefully reviewing the existing medications to assess the patient's systemic condition and considering the potential effects of the medication on oral health, the next consideration relates to drugs administered or prescribed for the patient by the dentist. The first consideration is "are there any absolute contraindications to the medication that will be prescribed," such as a drug allergy? ${ }^{16}$ Does the drug have the potential to exacerbate any of the patient's medical conditions (i.e., drug-physiology interaction), such as NSAIDs increasing the risk of gastrointestinal bleeding in a patient with gastric ulcers? ${ }^{16,25,26}$ Does the drug have the potential to interact with any of the over-the-counter, herbal supplements or medications reportedly taken by the patient such as erythromycin, inhibiting liver enzymes and decreasing the metabolism of the anti-coagulant Coumadin? ? $^{142}$ Patients taking two or more drugs and those whose drug list includes, but is not limited to, anti-convulsants, barbituates antibiotics, digoxin, Warfarin, amiodarone, or dexamethasone are at high risk of developing drug-drug interactions. ${ }^{16,26}$ Many of these drugs are highly titrated and a small change in their blood levels can have a large physiological impact. ${ }^{16}$

Four drugs commonly used in dentistry, erythromycin, clarithromycin, metronidazole, and ketoconazole, inhibit cytochrome P450 enzymes. These enzymes are responsible for metabolizing many drugs. Their inhibition of drugs used in dentistry can significantly decrease the rate of drug metabolism and create a high potential for an ADR. Erythromycin and ketoconazole have the greatest potential to cause such inhibition. So, to avoid the risk of such drug-drug interactions, do not use these drugs in patients already taking other drugs. ${ }^{16}$
It may be useful to review reference books or websites at this point to see if there are any contraindications or precautions to taking a particular drug with a coexisting medical condition or to taking the medication with a currently prescribed medication. These references/ resources (Tables 5, 6, and 7) also help explain potential outcomes of ingesting a group of medications at one time. Some resources are very convenient such as Lexicomp's electronic drug interaction software that allows you to enter the drug in question and cross check it for interactions. Importantly, pharmacists can also be consulted to clarify seemingly ambiguous information. ${ }^{1,16,26}$

It is important to note most medications prescribed for dental purposes are prescribed for only a short duration and many have a large margin of safety, which reduces the risk of ADRs. ${ }^{16,28}$ It may also be possible, in consultation with the patient's physician, to temporarily change or suspend an interacting medication they have prescribed during the duration of the dental prescription, though that is seldom necessary. ${ }^{16}$

In order to avoid drug toxicity the prescriber must be aware of how the drug will be eliminated when selecting a drug or determining dosages. This is especially important if the patient has known renal or hepatic disease, since these are the most common routes of elimination. If they are available, some laboratory values may serve as guidelines for prescribing drugs eliminated by the kidney or liver (Table 8).

Patients of advanced age may be at increased risk of suffering the respiratory depressive effects of some medications such as benzodiazepines and opioids. They may be less able to compensate quickly for medications that alter cardiovascular function, such as epinephrine ${ }^{1}$, and they may have an atypical adverse drug response such as altered mental status. ${ }^{4} 29$ It should be noted few adverse drug events have been clearly attributed to the changes that occur in the processes of absorption, distribution, and elimination as a result of normal aging. ${ }^{1,3}$ Risks associated with altered drug metabolism and elimination are almost always due to the presence of a known systemic disease affecting cardiac, kidney, or liver function. ${ }^{1,3,5}$ 
Some drugs present an increased risk of toxicity in older individuals, even without a drug interaction. In addition to screening for potential adverse drug interactions knowledge of maximum doses of the drugs to be prescribed for a dental purpose is critical whether the individual is a child, healthy adult, an individual with renal failure, or a frail elder. ${ }^{1,16}$ A decrease in dosage for aged individuals may be recommended for some medications commonly used in dentistry ${ }^{29}$ (Table 9). Due to normal physiologic changes in elimination associated with aging and altered distribution as a result of decreased body mass, dosage of these drugs should be reduced by $50 \%$ or to the lowest therapeutic dose for individuals under 100 pounds and patients over 85 years old. $^{29,30,31}$

It is important to keep in mind the characteristics of the drugs frequently prescribed in dentistry along with prescribing patterns. In addition to the short duration of use, the number of frequently prescribed medications is limited and their associated ADRs are well documented and are readily found in reference materials. ${ }^{5,14,16}$ Drug classes commonly used in general dentistry include analgesics, antibiotics, antifungals, antivirals, anesthetics, vasoconstrictors, and sedatives. There are generally three to five commonly used medications in each class, though generally any one practitioner limits their prescribing pattern to one or two in each class. A limited list of these drugs and their potential drug interactions are found in Table 10. The individual provider should be very familiar with the properties of the drugs they commonly use.

A report can be made to the Federal Drug Administration if after all precautions have been taken and an unexpected ADR appears to have occurred, either from a single or a combination of prescriptions (http://www.fda.gov/medwatch /report/hcp.htm). Any patient could have an idiosyncratic reaction or an unexpected outcome to a medication. ${ }^{16}$ However, most potential adverse drug effects, events, and interactions can and should be anticipated so they can be prevented. ${ }^{1,3,4,16}$

The dental provider, of course, bears responsibility for ADRs related to medications prescribed for oral health reasons. But, it should be noted the dental care provider does not have the responsibility of identifying and eliminating risks for ADRs among medications prescribed by other providers. That is the responsibility of the physicians, nurses, and pharmacy staff who prescribe and dispense those medications. However, if an ADR is suspected or evident, it should be brought to the attention of the other providers.

\section{Conclusion}

Managing patients who have multiple diseases and are taking multiple medications is complex and comes with risk. The dentist should be prepared to safely manage such patients. In the year 2000, 2.8 billion prescriptions were filled in the United States, enough for everyone to have ten prescriptions. So far there has not been a clear estimate of ADRs that occur for outpatients. It is estimated each year approximately 350,000 ADRs occur in nursing homes and over two million occur in hospitals with over 100,000 of those resulting in death. ${ }^{26}$

The medical conditions necessitating polypharmacy and the medications themselves will impact our patients' oral health and the way we practice. Evaluating the potential for adverse outcomes of polypharmacy in the aged is often complicated by the presence of several chronic diseases or conditions that may impair communication, cognition, and/or the ability to comply with a complicated drug regimen. ${ }^{1,5,16,31}$ The complexity of these situations calls for more than diligence on the part of the practitioner. It is necessary to complete a careful review of the patient's health history and have knowledge of the appropriate uses and limitations of our dental drug armamentarium. Dental providers should be familiar with their physician and pharmacy colleagues and be familiar with easy to access, up-to-date medical and pharmacological information. Dental providers will have to reach across disciplines to remain current and informed, as well as to inform others, about the adverse effects on oral health from medical diseases and their management. They must also be knowledgeable about their individual patients' diseases and medications in order to better prevent ADRs and untoward outcomes to dental treatment. 
Table 1. Types of adverse drug reactions. ${ }^{14,16,32,33}$

Allergic

Side effect

Drug toxicity

Drug-drug interaction

Drug-physiology interaction

Drug-laboratory test interaction

Idiosyncratic
Administration of the drug causes an undesirable immunologic response, i.e., rash, anaphylaxis, which is often unpredictable.

Undesirable effect occurs which is expected or predictable at therapeutic doses, i.e., nausea, dry mouth. Side effects are the most common adverse effects.

Occurring most commonly in children and frail elders, this is when a physiologic system is damaged from doses over therapeutic levels, i.e., nephrotoxicity from over ingestion of NSAIDs. Toxicity is usually predictable.

The absorption, distribution, metabolism, and/or excretion of one drug is altered by the administration of another drug, i.e., erythromycin taken with digoxin increases the digoxin level or NSAIDs and methotrexate interactions are usually predictable.

The presence of a drug at therapeutic levels adversely alters a physiologic system - can overlap with a side effect, i.e., administration of Clindamycin can result in colitis and diarrhea. Such interactions are usually predictable.

There is no effect on the physiologic system being tested, but a false positive or false negative test result, i.e., amoxicillin can cause a false-positive urine glucose test. Such interactions are usually predictable.

By definition these are unpredicted physiologic or psychological responses occurring at therapeutic doses. These are unique to an individual. 
Table 2. Steps in the assessment of and prescribing for the polypharmacy patient.

A. Review the existing medication list.

1. Could any of these drugs be required during a medical emergency?

e.g., Nitroglycerin - angina ${ }^{10}$; Inhalers - COPD exacerbation ${ }^{11}$

2. Why is the patient taking these particular medications? Group by category to aid in assessing overall risk in patient care and management.

e.g., antihypertensive, anticoagulant, immunosuppressive, antidepressant, etc.

3. Do any have the potential to contribute to a complication or even create an emergency situation?

e.g., Warfarin - excessive bleeding ${ }^{1}$; Prednisone - adrenal insufficiency ${ }^{3}$; Insulin hypoglycemia $^{16}$

4. Could any of these drugs compromise our desired treatment outcome?

e.g., Vincristine - delayed healing ${ }^{14}$; Echinacea - inhibition of erythromycin and ketokonazole ${ }^{34,35,36}$

5. Do any of these drugs have potential oral side effects?

e.g., Dilantin, Nifedipine - gingival hyperplasia; calcium channel blockers - lichenoid reactions; antihistamines, diuretics - xerostomia ${ }^{5,14,18,24}$

B. Considerations prior to administering or prescribing dental related medications

1. Does this person have a specific drug allergy to a drug you intend to prescribe?

e.g., taking penicillin has resulted in a skin rash ${ }^{14}$

2. Is this drug contraindicated for use given any of this patient's medical conditions?

e.g., NSAIDs with history of gastrointestinal ulcers or alcohol abuse ${ }^{14,37}$

3. Is there a potential for an adverse drug interaction with the patient's existing medications?

e.g., erythromycin reducing Warfarin clearance by $30 \%{ }^{14,27}$

4. Where will the dental drugs be metabolized and is there any indication drug elimination will be a problem for this patient?

e.g., elderly may have decreased elimination of penicillin, cephalosporin, erythromycin ${ }^{29}$; bisphosphonates - bone necrosis ${ }^{45}$ 


\section{Could any of the dental drugs contribute to an emergency situation?}

e.g., Prednisone - risk of non-compliance and patient failing to take prescribed dose resulting in adrenal crisis $^{1,14,16}$

6. Is the dose prescribed in a safe range for the patient's size and state of health, i.e., at or below the maximum safe dose?

e.g., Acetaminophen prescribed should not exceed $4 \mathrm{~g}$ per day for adults, but hepatotoxicity has occurred with $<4 \mathrm{~g}$ in patients with cirrhosis ${ }^{14,32}$

Table 3a. Potential drug related oral health/management complications.

\begin{tabular}{|c|c|c|}
\hline Drug Groups & Example Drugs & Management Problems \\
\hline Anticoagulants & Aspirin, Warfarin* & Excessive bleeding \\
\hline Immunosuppressants & $\begin{array}{c}\text { Corticosteroids* } \\
\text { Immunosuppresants for } \\
\text { organ transplants* }\end{array}$ & $\begin{array}{c}\text { Increase risk of bacterial and fungal } \\
\text { infection, poor stress response }\end{array}$ \\
\hline Chemotherapeutic agents & Vincristine & $\begin{array}{c}\text { Delayed healing, mucositis, fungal } \\
\text { infections }\end{array}$ \\
\hline $\begin{array}{c}\text { Sedative hypnotics*, } \\
\text { narcotics, barbiturates }\end{array}$ & $\begin{array}{c}\text { Tylenol \#3, Valium, } \\
\text { Demerol }\end{array}$ & Respiratory suppression, fall risk \\
\hline Hypoglycemics & Insulin*, sulfonylureas & Hypoglycemia \\
\hline $\begin{array}{c}\text { Bisphosphonate bone } \\
\text { stabilizers }\end{array}$ & $\begin{array}{c}\text { Pamidronate (Aredia) } \\
\text { Alendronate (Fosmax) }\end{array}$ & $\begin{array}{c}\text { Delayed bone healing, } \\
\text { bone necrosis }\end{array}$ \\
\hline
\end{tabular}

*highly titrated drugs - narrow margin of safety ${ }^{1,3,16}$

Table 3b. Natural products that may alter dental management. ${ }^{34,35,36,38,39}$

\begin{tabular}{|c|c|}
\hline Compound & Possible Dentally Relevant Problem \\
\hline $\begin{array}{c}\text { Feverfew } \\
\text { Garlic } \\
\text { Ginger } \\
\text { Ginko Biloba } \\
\text { Bilberry } \\
\text { Dong Quai } \\
\text { St. John's Wort }\end{array}$ & May increase bleeding \\
\hline $\begin{array}{c}\text { Echinacea } \\
\text { St. John's Wort }\end{array}$ & $\begin{array}{c}\text { These herbs inhibit liver enzymes so they may } \\
\text { potentiate the liver enzyme (cytochrome P450) } \\
\text { inhibiting the effect of erythromycin and } \\
\text { ketokonazole. }\end{array}$ \\
\hline $\begin{array}{l}\text { Ephedra (Ma-Huang) } \\
\text { Bitter orange }\end{array}$ & $\begin{array}{l}\text { May increase blood pressure and heart rate due } \\
\text { to anxiety or if epinephrine/vasoconstrictor used. }\end{array}$ \\
\hline Kava-Kava & $\begin{array}{l}\text { Hepatotoxicity, especially in those taking other } \\
\text { medications metabolized in the liver. Sedative } \\
\text { effects. }\end{array}$ \\
\hline Valerian & $\begin{array}{l}\text { May potentiate the effects of sedative Hypnotics } \\
\text { and anti-anxiety drugs }\end{array}$ \\
\hline
\end{tabular}


Table 4. Oral side effects of drug classes and their possible uses. ${ }^{3,5,14,16,18,24,40,41}$

\begin{tabular}{|c|c|c|c|}
\hline Oral side effect & Drug Class & Example (Generic) & May be used to treat: \\
\hline \multirow{4}{*}{ Xerostomia } & Antihistamine & Claritin (Loratadine) & Hay fever \\
\hline & Antidepressant & Zoloft (Sertraline) & $\begin{array}{l}\text { Obsessive Compulsive } \\
\text { Disorder }\end{array}$ \\
\hline & $\begin{array}{l}\text { Antihypertensive Calcium } \\
\text { channel blocker }\end{array}$ & Norvasc (Amlodipine) & High blood pressure \\
\hline & Diuretics & Lasix (Furosemide) & High blood pressure \\
\hline \multirow{2}{*}{ Fungal infection } & Antibiotics & Tetracycline & Periodontal disease \\
\hline & Immunosuppressant & Prednisone & Rheumatoid Arthritis \\
\hline Mucositis & Anti-neoplastic & Adrucil (5-fluorouracil) & $\begin{array}{l}\text { Chemotheraputic for breast } \\
\text { cancer }\end{array}$ \\
\hline \multirow{3}{*}{ Tooth discoloration } & Antibiotics & Minocin (Minocycline) & H.Pylori caused gastric ulcers \\
\hline & Antimicrobials & Peridex (chlorhexidene) & Periodontal disease \\
\hline & Fluorides & Stannous Fluoride & Cavity prevention \\
\hline \multirow{2}{*}{ Dygeusia } & Oral hypoglycemics & $\begin{array}{l}\text { Glucotrol (Glipizide) } \\
\text { Vasotec }\end{array}$ & Anti-diabetic \\
\hline & $\begin{array}{l}\text { Anti-hypertensive Ace } \\
\text { inhibitor }\end{array}$ & (Enalapril) & Hypertension \\
\hline \multirow{3}{*}{ Gingival hyperplasia } & Anti-convulsant & Dilantin (Phenytoin) & Epilepsy \\
\hline & $\begin{array}{l}\text { Anti-hypertensive Calcium } \\
\text { channel blocker }\end{array}$ & Procardia (Nifedipine) & High blood pressure \\
\hline & Immunosuppressant & $\begin{array}{l}\text { Sandimmune } \\
\text { (Cyclosporin) }\end{array}$ & $\begin{array}{l}\text { Prevent organ transplant } \\
\text { rejection }\end{array}$ \\
\hline Stomatitis & $\begin{array}{l}\text { Anti-hypertensive } \\
\text { Ace Inhibitor }\end{array}$ & Capoten (Captopril) & High blood pressure \\
\hline Lichenoid reactions & Diuretics & $\begin{array}{l}\text { Thiazide } \\
\text { (HCTZ) }\end{array}$ & High blood pressure \\
\hline Mucosal Burns & Anti inflammatory & $\begin{array}{l}\text { Ecotrin (Aspirin) - if } \\
\text { dissolved in the mouth }\end{array}$ & Osteoarthritis \\
\hline \multirow{2}{*}{$\begin{array}{l}\text { Delayed Bone Healing } \\
\text { Bone Necrosis }\end{array}$} & Bisphosphonates & Pamidronate (Aredia) & Bone loss in cancer \\
\hline & & Alendronate (Fosmax) & Bone necrosis \\
\hline
\end{tabular}


Table 5. Useful Internet based Web sites relative to drugs and drug interactions.

www.ada.org - The American Dental Association web site contains resources and connects to a variety of medically related sites. Members can look through a long, well-researched list of useful web sites related to drugs and health.

www.dentalgate.com - This site has two different search features, one for the World Wide Web and another for medicine, especially designed for dentistry.

www.drugs.com - This is a comprehensive and up-to-date prescription drug information site for consumers and professionals with fast, easy searching of over 24,000 approved medications.

www.drweil.com - This site contains pages called "Herbal Medicine Chest" and "Home Health Remedies" describes availability, dosages, and warnings. The site is available to the general public.

www.factsandcomparisons.com or www.drugfacts.com - This site contains headlines, drug updates, recent drug approvals, and information on resources for purchase as well as an option to subscribe to "efacts" which provides drug facts and comparisons, as well as information about herbals, OTC meds, and chemotherapeutics and a host of other topics.

www.fda.gov/cder/drug/default.htm - The Center for Drug Evaluation and Research web page has information on all the drugs regulated by the FDA, which is all drugs.

www.fda.govlopacom/hpchoice.html - This site provides information on adverse reactions.

www.healthgate.com - This site provides access to medicine searches as well as health news.

www.hiv-druginteractions.org - An excellent site for HIV drug interactions as well as interactions with recreational/abuse drugs and with herbs.

www.lexi.com - This site offers handheld software, downloadable updates, access to Lexi-Comp Online for member health professionals including Lexi-Interact and Lexi-Drugs for Dentistry, new drug information, and special alerts and patient education.

www.mcp.edu/herbal - This site includes in-depth monographs, clinician information summaries, patient fact sheets, interactions and toxicity information for herbal medicines, dietary supplements, vitamins and minerals. The site is available to the general public.

www.medscape.com - This is a searchable site with an extensive medical-based home page that can be customized for your personal interests. It will send topics, such as pharmacology updates, to your computer to allow you to keep current on areas of interest.

www.mosbysdrugconsult.com - This site contains full prescribing information for pharmaceuticals. It also includes customizable patient information handouts in English and Spanish and drug interactions software.

www.naturaldatabase.com - This site contains a drug interaction checker and an interactive component for health professionals. 
Table 5. Continued

www.nlm.nih.gov - This site has a powerful search feature that looks at a large range of databases and searches out complete articles on specific topics.

www.pdrhealth.com - Registration is free, includes information on pharmaceuticals and herbals.

www.personalhealthzone.com/pg000059.html - Prescription drug interactions and warnings

relative to herbs and supplements.

www.purecaps.com - Members and nonmembers can access the site for information on alternative medicinals that includes: botany, usage, active constituents and mechanisms of action, dosages, cautions and contraindications, as well as depletions and interactions by drug name.

www.rxlist.com - This site has a very comprehensive list of drug indications, contraindications, interactions, etc. It also has an extensive list of medical diseases and how they are managed. Some of the explanations of the diseases are presented in a short video interview format, which makes it an interesting educational resource.

www.seniorcarepharmacist.com - This site provides Seniors information about managing the medications they are taking and issues specific to elders and medications. The site also assists users in locating specialist in geriatric pharmacology in their area.

Table 6. Authors choice of drug text references to keep in the office (updated annually).

Texts may be found in medical bookstores or on line such as noted. Note there may be other online resources besides those noted.

Dental Therapeutics - American Dental Association Guide, $3^{\text {rd }}$ Edition (www.ada.org)

Facts and Comparisons (www.factsandcomparisons.com or www.drugfacts.com)

Lexicomp's Drug Information Handbook for Dentistry, $9^{\text {th }}$ Edition. Editors Wynn RL, Meiller TF, Crossley. Hudson Ohio, 2003. (www.lexi.com/web/index.jsp, www.amazon.com)

The Little Dental Drug Booklet (www.dentalstudents.com)

Mosby's Dental Drug Book (www.us.elsevierhealth.com/Dentistry/index.jsp)

Natural Medicines Comprehensive Database $5^{\text {th }}$ Ed. (www.amazon.com)

2004 Physician's Desk Reference (www.pdrbookstore.com/Merchant2/merchant.mv, www.amazon.com)

2004 Physician's Desk Reference for Non-prescription Drugs and Dietary Supplements (www.pdrbookstore.com/Merchant2/merchant.mv, www.amazon.com) 
Table 7. Available computer and PDA drug information software.

Software may be found on line such as noted. Note there may be other online resources besides those noted.

Facts and Comparisons, (www.factsandcomparisons.com or www.drugfacts.com)

Lexi-Comp On-Hand Databases: Lexi-Drugs for Dentistry, Lexi-Interact

(www.lexi.com/web/index.jsp, www.amazon.com)

Mobile Physician's Desk Reference (www.pdrbookstore.com/Merchant2/merchant.mv, www.amazon.com)

Mosby's Drug Consult Networkable CD (www.us.elsevierhealth.com/Dentistry/index.jsp)

Mosby's Drug Consult Handheld Software (www.us.elsevierhealth.com/Dentistry/index.jsp)

Natural Medicines Comprehensive Database (www.naturaldatabase.com/skyinfo.asp $)$

New Mentor, Dental Drug Booklet (www.newmentor.com)

Table 8. Guidelines for compromised renal or hepatic function. 5, 29, 42

\begin{tabular}{|c|c|c|c|c|}
\hline $\begin{array}{c}\text { Potential } \\
\text { Impairment }\end{array}$ & $\begin{array}{c}\text { Examples of dental } \\
\text { drugs ellminated }\end{array}$ & Lab test & Range & $\begin{array}{c}\text { Margin of safety for dental } \\
\text { prescrlbing }\end{array}$ \\
\hline Renal & $\begin{array}{c}\text { Amoxicillin } \\
\text { Cephalosporin } \\
\text { Penicillin } \\
\text { Tetracycline }\end{array}$ & $\begin{array}{c}\text { GFR } \\
\text { (Creatinine } \\
\text { Clearance) }\end{array}$ & $\begin{array}{c}<10 \mathrm{ml} / \mathrm{min} \\
10-50 \mathrm{ml} / \mathrm{min} \\
>50 \mathrm{~mL} / \mathrm{min}\end{array}$ & $\begin{array}{c}\text { One dose q 24 hrs } \\
\text { One dose q } 8-12 \mathrm{hours} \\
\text { One dose q } 8 \text { hours }\end{array}$ \\
\hline Hepatic & $\begin{array}{c}\text { Acetaminophen } \\
\text { Codeine } \\
\text { Diazepam } \\
\text { Erythromycin } \\
\text { Ibuprofen } \\
\text { Ketoconazole } \\
\text { Lidocaine } \\
\text { Lorazepam } \\
\text { Prednisone }\end{array}$ & AST, ALT, liver \\
& transaminases & $30-40 \mathrm{u} / \mathrm{l}$ & $\begin{array}{c}\text { If greater than } 4 \text { times normal, } \\
\text { do not use drugs that are toxic } \\
\text { to or metabolized by the liver }\end{array}$ \\
\hline
\end{tabular}

Table 9. Route of elimination for dental drugs that may require dosage adjustments in frail older patients even in the absence of frank renal or hepatic disease*., ${ }^{1,29}$

\begin{tabular}{|c|c|}
\hline \multicolumn{2}{|c|}{ Renal Elmination } \\
\hline Drug class & Drug \\
\hline Antibiotic & $\begin{array}{c}\text { Amoxicillin } \\
\text { Cephalosporin } \\
\text { Tetracycline }\end{array}$ \\
\hline Antifungal & Fluconazole \\
\hline \multicolumn{2}{|c|}{ Hepatic Elimination } \\
\hline Drug class & Drug \\
\hline Pain reliever & lbuprofen \\
\hline Antibiotic & Erythromycin \\
\hline Local anesthetic & Lidocaine \\
\hline Sedative/anxiolytic & $\begin{array}{l}\text { Diazepam } \\
\text { Lorazepam }\end{array}$ \\
\hline
\end{tabular}

* This does not refer to prophylactic regimens such as those suggested by The American Heart Association for SBE prophylaxis 
Table 10. Adverse outcomes and interactions with common "dental drugs." "4, 14, 27, 32, 37, 38, 42, 43, 44 (Drugs listed may interact with more than the example drug listed)

\begin{tabular}{|c|c|c|c|}
\hline Drug class & $\begin{array}{c}\text { Common drugs used in } \\
\text { dentistry }\end{array}$ & $\begin{array}{l}\text { Interacts with already } \\
\text { prescribed (example) }\end{array}$ & $\begin{array}{l}\text { Potential adverse } \\
\text { outcome(s) }\end{array}$ \\
\hline \multicolumn{4}{|l|}{ Analgesic } \\
\hline Narcotic & Tylenol \#3* & $* * * * * * * * *$ & Respiratory depression \\
\hline \multirow[t]{5}{*}{ Non-narcotic } & NSAIDs & Warfarin & Excessive bleeding \\
\hline & & Ace inhibitors & $\begin{array}{l}\text { Decreased hypotensive } \\
\text { action }\end{array}$ \\
\hline & & Lithium & $\begin{array}{l}\text { Increased serum } \\
\text { concentration }\end{array}$ \\
\hline & Acetaminophen & Methotrexate & Renal failure \\
\hline & & NSAIDs & Nephrotoxicity \\
\hline \multirow[t]{5}{*}{ Antibiotic } & Clindamycin* & $* * * * * * * * * *$ & Colitis and diarrhea \\
\hline & Cephalosporin* & $* * * * * * * * * *$ & Impaired clotting \\
\hline & Erythromycin+ & Digoxin & Increases digoxin level \\
\hline & Penicillin & Probenecid & $\begin{array}{l}\text { Increases PCN } \\
\text { concentration }\end{array}$ \\
\hline & Metronidazole & Warfarin & Excessive bleeding \\
\hline \multirow[t]{4}{*}{ Anti-fungal } & Ketoconazole+ & Glyburide & $\begin{array}{l}\text { Increased hypoglycemic } \\
\text { effect } \\
\text { * anticoagulant effect }\end{array}$ \\
\hline & Nystatin & None known & \\
\hline & Clotrimazole & None known & \\
\hline & Fluconazole & Warfarin & \\
\hline \multirow[t]{2}{*}{ Anti-viral } & Acyclovir & None known & \\
\hline & Val acyclovir & None known & \\
\hline Anti-inflammatory & Prednisone & NSAIDs, Acetaminophen & $\begin{array}{l}\text { Hepatotoxicity } \\
{ }^{*} \text { side effects of NSAIDs }\end{array}$ \\
\hline \multirow[t]{3}{*}{ Anesthetic } & Lidocaine & ${ }^{*} \mathrm{H} 2$-blocker, ranitidine & ${ }^{*}$ lidocaine concentrations \\
\hline & Prilocaine & CNS depressants & Respiratory depression \\
\hline & Articaine & CNS depressants & Respiratory depression \\
\hline \multirow[t]{2}{*}{ Vasoconstrictor } & Epinephrine & MAO inhibitors & Increased blood pressure \\
\hline & Levonordephrine & *-blockers for both & \\
\hline \multirow[t]{2}{*}{ Sedatives } & Diazepam* & $* * * * * * * * * * *$ & $\begin{array}{l}\text { Respiratory depression, } \\
\text { fall risk }\end{array}$ \\
\hline & Lorazepam & CNS depressant & $\begin{array}{l}\text { Respiratory depression, } \\
\text { fall risk }\end{array}$ \\
\hline
\end{tabular}

* Increased risk of toxicity and adverse event in the aged - even without a drug interaction

+ Do not use these drugs in patients taking other drugs to avoid the risk of drug-drug interaction. 


\section{References}

1. Heft MW, Mariotti AJ. Geriatric pharmacology. Dental Clinics of North America 2002; 46(4): $869-85$, xii.

2. Jainkittivong A, Aneksuk V, Langlais RP. Medical health and medication use in elderly dental patients. J Contemp Dent Pract 2004;(5)1:031-041.

3. Paunovich ED, Sadowsky JM, Carter P. The most frequently prescribed medications in the elderly and their impact on dental treatment. Dental Clinics of North America 1997; 41(4): 699-726.

4. Hanlon JT, Schmader KE, Koronkowski MJ. Weinberger M. Landsman PB. Samsa GP. Lewis IK. Adverse drug events in high risk older outpatients. Journal of the American Geriatrics Society 1997; 45(8): 945-948.

5. Prescribing Medications in the Geriatric Patient In: Ship JA, Mohammad AR, eds. Clinician's Guide to Oral Health in Geriatric Patients, First Edition. Baltimore, MD: The American Academy of Oral Medicine; 1999: 52-53.

6. Drug Interactions In: Practical Geriatric Theraputics. Sloan RW ed. Oradell, New Jersey: Medical Economic Books; 1986:39.

7. Field TS, Gurwitz JH, Avorn J, et al. Risk Factors for Adverse Drug Events Among Nursing Home Residents. Arch Intern Med 2001; 161:1629-1634.

8. Cooper JW. Probable Adverse Drug Reactions in a Rural Geriatric Nursing Home Population: A Four Year Study. J Am Geratr Soc 1996; 44:194-7.

9. Gray SL, Sager M, Lestico MR, et al. Adverse Drug Events in Hospitalized Elderly. J Gerontol A Biol Sci Med Sci 1998; 53A:M59-M63.

10. schemic Heart Disease. In: Little JW, Falace DA, Miller CS, eds. Dental Management of the Medically Compromised Patient, Sixth Edition. St. Louis MO: Mosby; 2002:79-93.

11. Pulmonary Diease. In: Little JW, Falace DA, Miller CS, eds. Dental Management of the Medically Compromised Patient, Sixth Edition. St. Louis MO: Mosby; 2002:125-146.

12. Diabetes. In: Little JW, Falace DA, Miller CS, eds. Dental Management of the Medically Compromised Patient, Sixth Edition. St. Louis MO: Mosby; 2002:248-270.

13. Organ Transplantation. In: Little JW, Falace DA, Miller CS, eds. Dental Management of the Medically Compromised Patient, Sixth Edition. St. Louis MO: Mosby: 2002:501-525.

14. Drug Information Handbook, 12th Edition -. Lavy CF, Armstrong LL, Goldman MP, et. al. eds. Hudson Ohio: Lexicomp:2004;661,943,1509.

15. Brawn LA, Castleden CM. Adverse drug reactions: An overview of special considerations in the management of the elderly patient. Drug Safety 1990; 5:421.

16. Jacobsen PL. Adverse Drug Reactions. In: Silverman, ed. Essentials of Oral Medicine. Hamilton, London: BC Decker Inc: 2001;107-110.

17. Firth NA, Reaade PC. Angiotensin converting enzyme inhibitors implicte in oral mucosal lichenoid reactions. OOOOE 1989; 67:441.

18. Ciancio SG. Medications' impact on oral health. JADA 2004;135:1440-1448.

19. Thomson WM, Chalmers JM, Spencer AJ, et al. Medication and dry mouth: Findings from a cohort study of older people. Journal of Public Health Dentistry 2000; 60(1):12-20.

20. Narhi TO, Vehkalahti MM, Siukosaari $P$, et al. Salivary findings, daily medication, and root caries in the old elderly. Caries Research 1998; 32(1):5-9.

21. Kamen, PR. Periodontal care. Dental Clinics of North America 1997; 41(4):751-62.

22. Mattes RD, Cowart BJ, Schiavo MA, et al. Dietary evaluations of patients with smell and taste disorders. Am J Clin Nutr 1990; 51:2233.

23. Ship JA, Chavez EM. Special Senses: Disorders of Taste and Smell. In: Silverman, et al, eds. Essentials of Oral Medicine. Hamilton, London: BC Decker Inc.: 2001:277-288.

24. Guggenheimer J. Oral Manifestations of Drug Therapy. Dent Clin N Am 2002; 46:857-868.

25. Gastrointestinal Disorders. In: Little JW, Falace DA, Miller CS, eds. Dental Management of the Medically Compromised Patient, Sixth Edition. St. Louis MO: Mosby: 2002;188-202

26. www.FDA.gov 
27. Hersh EV. Adverse drug interactions in dental practice: interactions involving antibiotics. Part II of a series. J Am Dent Assoc 1999; 130(2):236-51.

28. Moore, PA, Gage, TW, Hersh,EV, et. al., Adverse Drug Interactions in Dental Practice: Professional and Educational Implications. Part I of a series. J Am Dent Assoc 1999; 130(2):47-54.

29. Schwartz JB. Clinical Pharmacology. In: Hazzard WR, Blass JP, Ettinger WH, et al eds. Principles of Geriatric Medicine and Gerontology, Fourth Edition. USA: McGraw Hill; 1999:303-331.

30. Merck Manual of Geriatrics, Third Edition. Beers MH and Berkow R, eds. Whitehouse Station, New Jersey, Merck Research Laboratories: 2000;54-74.

31. Logue RM. Self Medication and the Elderly: How technology can help. AJN 2002; 102(7):51-55.

32. Geriatric Dosage Book, 9th Edition . Semla TP, Beizer JL, Higbee MD eds. Hudson Ohio; Lexicomp: 2003;21,315.

33. http://www.pdrhealth.com/index.html

34. http: mcp.edu/herbal/default/htm

35. Ang-Lee MK, Moss J, Yuan CS. Herbal Medicines and Peri-operative Care. JAMA 2001; 286(2): 208-216

36. Miller LG. Herbal Medicinals: Selected Clinical Considerations Focusing on Known Potential Drug Interactions. Archives of Internal Medicine 1998; 9:158(20):2200-2211.

37. Haas DA. Adverse drug interactions in dental practice: interactions associated with analgesics, Part III in a series. Journal of the American Dental Association 1999; 130(3):397-407.

38. Hersh EV, Moore PA. Drug interactions in Dentistry: The Importance of Knowing your CYPs. JADA 2004; 135:298-311.

39. Meredith MJ, Herbal nutriceuticals: a primer for dentists and dental hygienists. J Contemp Dent Pract 2001;(2)2:001-024.

40. http:nlm.nih.gov/medlineplus/drugsinfo/medmaster/a686002.html

41. Abdollahi M, Radfar M. A review of drug induced oral reactions. J Contemp Dent Pract 2003 (4) 1: 010-031.

42. Chronic Renal Failure and Dialysis In: Little JW, Falace DA, Miller CS, eds. Dental Management of the Medically Compromised Patient, Sixth Edition. St. Louis MO: Mosby: 2002;147-160.

43. Moore PA. Adverse drug interactions in dental practice: interactions associated with local anesthetics, sedatives and anxiolytics. Part IV of a series. Journal of the American Dental Association 1999; 130(4):541-54.

44. Yagiela J. Adverse Drug Interactions in Dental Practice: Interactions Associated with Vasoconstrictors. Part V of a series. Journal of the American Dental Association 1999; 130(2):701-09.

45. Carter G, Goss AN, Doecke C. Bisphosphonates and avascular necrosis of the jaw: a possible association. Med J Aust. 2005 Apr 18;182(8):413-5. 
About the Authors

\section{Potor L. Jacobsen, PhD, DDS}

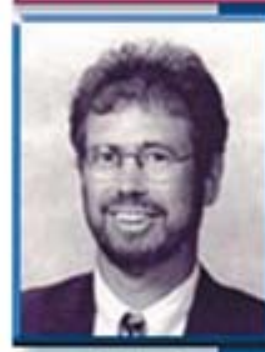

Dr. Peter Jacobsen lectures extensively on the topics of dental pharmacology and over-the-counter drugs and products. His graduate training is in comparative pharmacology and toxicology. He is the past Chairperson of the Council on Dental Therapeutics of the American Dental Associations and serves as the Director of the ORal Medicine Clinic at the University of Pacific, School of Dentistry

University of the Pacific

School of Dentistry

2155 Webster St. Room 400

San Fransisco, CA 94115

e-mall: placobse@pacific.edu

\section{Elisa M. Chávez, DDS}

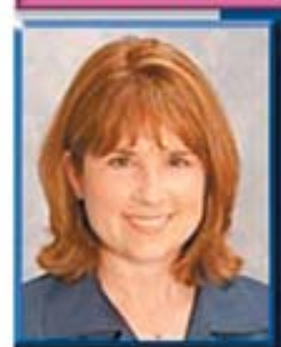

Dr. Chávez is an Assistant Professor In the Department of Removable

Prosthodontics of the Arthur A. Dugoni, School of Dentistry at the University of the Pacific in San Francisco, CA. She provides didactic instruction on the links between oral and systemic health and the provision of dental care for frall elders and medically compromised patients. She has developed and directs pre-and postdoctoral clinical outreach rotations at senior centers and skilled nursing facilities for Pacific. She also practices at the Jewish Home for the Aged in San Francisco, CA.

e-mail: echavez@pacific.edu 